\title{
Outlining the historical framework of the aviation sector in Turkey: A spatiotemporal approach
}

Dimitrios Tsiotas The fast-growing, capital-intensive, and fragile

Department of Planning and Regional Development,

University of Thessaly,

Department of Regional and

Economic Development, Agricultural University of Athens,

Greece

E-mail: tsiotas@uth.gr

Umut Erdem

(corresponding author) Department of City and Regional Planning, Faculty of Architecture,

Dokuz Eylul University, Turkey

Department of Human Geography and Spatial Planning,

Faculty of Geoscience,

Utrecht University,

The Netherlands

E-mails: umut.erdem@deu.edu.tr, u.erdem@uu.nl

K. Mert Cubukcu

Department of City and Regional Planning, Faculty of Architecture, Dokuz Eylul University, Turkey

E-mail: mert.cubukcu@deu.edu.tr

Keywords: aviation development, turkish airports, time-series analysis, deregulation, aviation policy structure of air transport makes the aviation sector crucial for national economic growth and regional development. Over a century old, Turkey's aviation sector has undergone a remarkable transition from a state-regulated market to a liberal, competitive one. This fundamental change has created an urgent need to quantitatively outline the historical and contextual framework of Turkey's air transport network in order to grasp its structural dynamics and thus obtain insights into the drivers of regional and air transport development. This paper uses time-series analysis to outline the historical framework of the aviation sector in Turkey based on air traffic and spatiotemporal data at the national and regional levels. The aim is to detect outlier changes in the historical air transport timeframe at both the national and regional levels and to define discrete periods in the history of Turkey's aviation sector. The results, discussed through the prism of transport policy and regional economies, provide structural insights into the dynamics of the Turkish aviation market. The findings reveal that the periods derived from the time-series analyses are consistent with the major changes discussed in the literature. 


\section{Introduction}

The aviation sector comprises an ecosystem of air transport-related service providers, such as airline companies, maintenance services, ground services, and airports. The evolution of the aviation sector in many countries has been driven by the power of neo-liberalisation, the transformation from state regulation to market-driven development (Palley 2005, Saad-Filho-Johnston 2005, Friedman 2009). The socioeconomic and political framework of this transformation has been the subject of many analyses focused on the United States (Button 1989), Europe (Button 1996, Barrett 2000), Australia, India (Hooper 1998), China (Wand et al. 2016), the UK, Spain (Lucio et al. 2001), Hungary (Béres et al. 2019), and Turkey (Cetin-Benk 2011). Neoliberal policies are driven by the forces of the free-market economy and privatisation (Polyani 1944). Under the policies, the state does not have a significant regulatory role but sometimes participates as an actor in the aviation market (Palley 2005, Friedman 2009).

In Turkey, aviation has become a dynamic, innovative, adaptive, and fast-growing sector, with an increasing share in both domestic and international air-transport demand and supply (Logothetis-Miyoshi 2018). Turkey's aviation market has been called 'successful' and part of the nation's 'soft power' (Selcuk 2013, Anaz-Akman 2017). Aviation activities in Turkey started in the 1900s with the construction of two hangars and a small runway in Istanbul. Today, Turkish Airlines (THY) is one of the fastest-growing airline companies in Europe, and Istanbul Airport is one of the biggest airports in the world (Erdem et al. 2019).

The deregulation of economy of Turkey and the privatisation of its state-owned enterprises (e.g. factories, refineries, roads, harbours) have accelerated the growth of the national economy and have helped restructure it according to liberalisation norms (Karaevli-Yurtoglu 2018).

According to the World Bank (2018), the Turkish economy is ranked 17th worldwide, with annual growth of about $6.7 \%$ on average. Since 2003 , the Turkish aviation sector has grown at an annual rate of about $8.2 \%$ (Cetin-Benk 2011), and a growth of $10 \%$ is expected for 2020 (Georgieva et al. 2015). According to the International Civil Aviation Organization (ICAO 2017), Turkey is ranked 11th worldwide and $5^{\text {th }}$ in Europe in the number of airline passengers. Moreover, the geopolitical location of Turkey is very important, because it is located at the meeting point of Europe and Asia.

Turkey's aviation sector is thus a unique case, and examining it can foster a better understanding of the forces underlying the 'market-state dichotomy' (Bruff 2011) and of their economic and political aspects (Boratav 2008, Pamuk 2014, Togan 2016). However, this sector has not been sufficiently studied. A large portion of the research - including Pamuk (2014), Togan (2016), Tekeli (2009), and Eraydin (2006) - have focused on the economic aspects of the transformation in Turkey, especially on the

Regional Statistics, Vol. 10. No. 2. 2020: 117-141; DOI: 10.15196/RS100204 
restructuring of the market in accordance with neoliberal policies. Further research is needed into the political, geographical, and socioeconomic configuration of Turkey's aviation sector. Thus, this study quantitatively outlines the historical framework of the air transport network in Turkey (TAN) using air traffic time data at both the national and regional levels to detect outlier changes in the historical air transport timeframe and identify milestones in the sector's history. This assessment can help us to understand the discrete periods in the history of Turkish aviation and lead to a deeper understanding of the dynamics driving the national and regional aviation markets in the country.

The remainder of this paper is organised as follows. Section 2 describes the methodological framework and data used by the study. Section 3 presents the results of the analysis concerning the configuration of the time periods in the long-term history of the aviation sector in Turkey. These time periods are then discussed and evaluated in Section 4. Finally, Section 5 concludes the paper.

\section{Methodology and Data}

The methodological framework of the study is based on time-series analysis (TSA). A time-series dataset can be considered as a vector $\mathbf{x}$ of successive real $(\mathrm{P})$ data $\mathbf{x}=\left(x_{1}, x_{2}, \ldots, x_{n}\right)$, which is arranged into time order $t\left(x_{1}\right)<t\left(x_{1}\right)<\ldots<t\left(x_{n}\right)$ and illustrates the temporal evolution of an attribute $X$ expressed by the vector-variable $X=\mathbf{x}$ (Das 1994). The TSA generally includes methods and techniques for modelling the time distribution of attribute $X$ and thus at extracting structural information from the available data $\left(x_{1}, x_{2}, \ldots, x_{n}\right.$; Das 1994 , Box et al. 2015).

In this study, TSA is used to extract the information required to classify the longterm history of the aviation sector into discrete periods. This is achieved by employing various TSA methods and techniques to produce outlier time points or cutting-points (thresholds) in the timeframe of the TAN's history. The discrete time periods are obtained by evaluating the frequencies and historical reference of these outlier values. The proposed methodological framework is the first to employ quantitative methods to classify historical events. As the flowchart shown in Figure 1 indicates, the overall approach is organised into two layers reflecting geographical scale (national and regional) and four computational steps: the computations, where the critical points (milestones) of the TAN's aviation history are estimated; the literature evaluation of the estimated critical points; the verification of the estimated time periods; and, finally, the conclusion making.

Regional Statistics, Vol. 10. No. 2. 2020: 117-141; DOI: 10.15196/RS100204 
Flow chart of the study's methodological framework

Figure 1

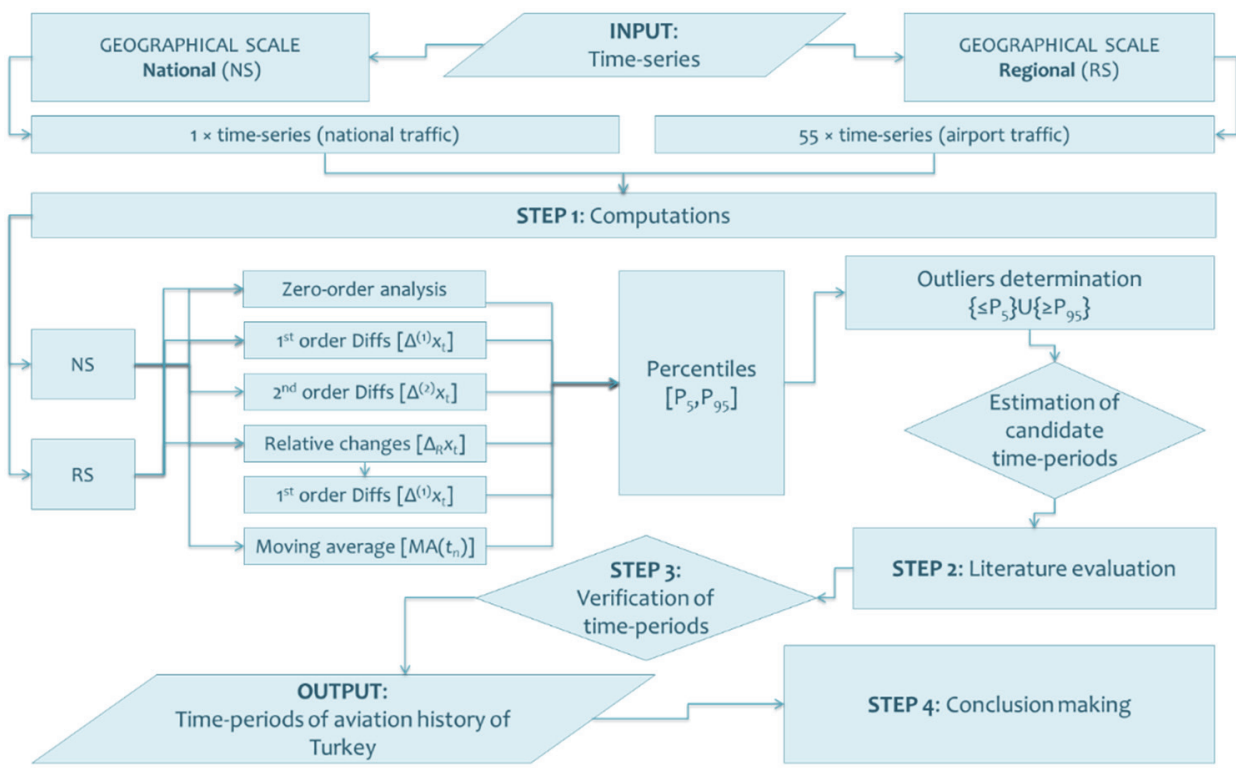

The TSA is based on annual passenger data, measured as the number of passengers transported in domestic and international flights from 1959 to 2018 (GDSAA 2018). The data are available at both the national (NS) scale (the aggregate domestic and international traffic in the country) and at the regional (RS) scale (for each of the 55 operating airports in the country), as shown in Figure 2. The data are obtained from the Turkish Statistical Service (TURKSTAT 2010) and the General Directorate of State Airports Authority (GDSAA 2018). Air passenger traffic is an effective proxy for air transport supply and can be used to examine the dynamics of the history of Turkey's aviation market and identify its main historical and contextual periods, as demand is heavily dependent on social, political, technological, and economic changes (Tsiotas-Polyzos 2015, Polyzos 2019).

Regional Statistics, Vol. 10. No. 2. 2020: 117-141; DOI: 10.15196/RS100204 
Time series of (left) the national (NS) and (right) regional (RS) air-passenger traffic in Turkey for 1960-2018

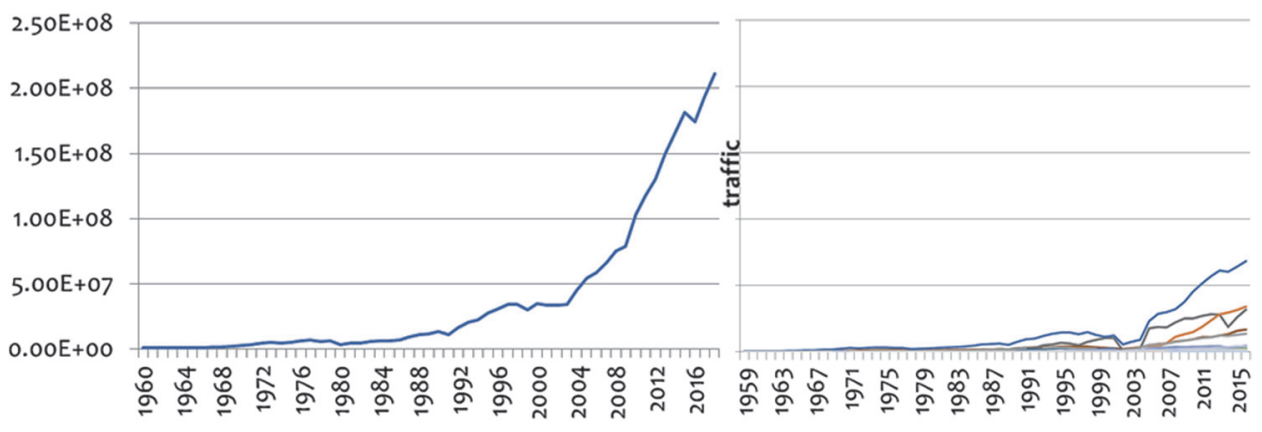

Source: GDSAA (2018).

Prior to the TSA, a stationarity assessment of the available time-series database is applied. Although an absence of stationarity is clearly observed in Figure 2, for the sake of completeness, an augmented Dickey-Fuller test (ADF) for a unit root (Shumway-Stoffer 2017) is applied to examine the hypothesis $\left(H_{\circ}\right)$ that a unit root is present in the model's time-series data:

$$
y_{t}=c+\boldsymbol{\delta} \mathrm{t}+\boldsymbol{\phi} \cdot y_{t-1}+\boldsymbol{\beta}_{1} \cdot \Delta y_{t-1}+\ldots+\boldsymbol{\beta}_{p} \cdot \Delta y_{t-p}+\boldsymbol{\varepsilon}_{t}
$$

where $\Delta$ is the differencing operator $\left(\Delta y_{t}=y_{t}-y_{t-1}\right), p$ is the (user-specified) number of lagged difference terms, $c$ is a drift term, $\delta$ is a deterministic trend coefficient, $\phi$ is an autoregressive coefficient, $\beta_{i}$ are regression coefficients of the lag differences, and $\varepsilon_{t}$ is a mean zero innovation process.

According to the expression shown in equation (1), the unit root hypothesis testing is expressed as follows (Shumway-Stoffer 2017):

$$
H_{o}: \phi=1 \text { vs. } H_{1}: \phi<1
$$

and the (lag adjusted) test statistic DFt is given by the following formula (ShumwayStoffer 2017):

$$
D F t=\frac{N(\widehat{\boldsymbol{\phi}}-1)}{\left(1-\widehat{\boldsymbol{\beta}}_{1}-\ldots-\widehat{\boldsymbol{\beta}}_{p}\right)}
$$

where the uppercase symbol '^` ' expresses the estimator of the variables.

The first step of the TSA is a computation of the fundamental time-series measures. The first method is based on computations of the first-order differences according to the following formula (Das 1994, Box et al. 2015):

$$
\Delta^{(1)} x_{t}=x_{t}-x_{t-1}, t=2, \ldots, n
$$

where $x_{t}$ is the value (score) of the time series at time $t$ and $x_{t-1}$ at time $t-1$. The firstorder differences capture the changes of attribute $X$ without removing the scale of the variable $\mathbf{x}$. These differences serve as a discrete analogy of the first derivative of 
a function and thus provide information about the monotonicity of the time series (Das 1994, Box et al. 2015).

Next, the relative changes of the time series are computed according to the following formula (Polyzos 2019):

$$
\Delta_{R} x_{t}=\frac{x_{t}-x_{t-1}}{x_{t-1}}=\frac{\Delta^{(1)} x_{t}}{x_{t-1}}, t=2, \ldots, n
$$

where $\Delta^{(1)} x_{t}$ are the (previously defined) first-order differences. The relative changes $\Delta_{R} x_{t}$ express the first-order differences $\Delta^{(1)} x_{t}$ divided by the magnitude of the pastpoints $x_{t-1}$. In finance, the measure of relative changes is similar to the measure of logarithmic returns (Hudson-Gregoriou 2015), but the latter is defined for a certain time period between the initial and final (closing) values of a share. Therefore, the measure of relative changes is useful because it is scale-free (Tsiotas 2019): It does not include the magnitude of the $x_{t}$ values since it expresses changes as percentages of the past-points $x_{t-1}$.

Next, the (simple) moving average statistic (Das 1994, Box et al. 2015) is computed as follows:

$$
M A\left(t_{n}\right)=\frac{(n-1) \cdot M A\left(t_{n-1}\right)+x\left(t_{n}\right)}{n}
$$

where $M A\left(t_{2}\right)=\frac{x\left(t_{1}\right)+x\left(t_{2}\right)}{2}$, and $n$ is the number of time-series nodes considered in time $t_{n}$. The moving average is used to smooth the short-term fluctuations and highlight the long-term effects in the time series (Das 1994, Box et al. 2015), which is useful for defining the long-term historical framework of the aviation sector in Turkey.

Additionally, the sign (or signum) function (Yun-Petkovic 2009) is considered in the analysis using the following equation:

$$
\operatorname{sgn}(x)=\frac{d}{d x}\left|x_{t}\right|=\left\{\begin{array}{l}
+, \text { if } x>0 \\
0, \text { if } x=0 \\
-, \text { if } x<0
\end{array}\right.
$$

where $\frac{d}{d x}$ is the derivative operant, and $x_{t}$ is a time-series node at time $t$. When applied, the sign-function 'binarises' (in absolute terms) the time series, since it transforms the time-series data into a set of values belonging to a discrete set $\{-1,0,1\}$. This transformation is useful for grouping values of the same sign in order to define historical time periods based on the time-series data.

The final task in the first step is computing the outlier values extracted from percentiles $P_{k}$ defined according to the following formula (Walpole et al. 2012):

$$
P_{k}=\left\{x_{i} \in \mathbf{x} \mid x_{i} \leq p_{k}\right\}
$$


where $\mathbf{x}$ is the time-series vector, $k$ is the bound of the percentile, $p_{k}$ is the score of the corresponding percentile belonging to the interval $p_{k} \in[\min (\mathbf{x}), \max (\mathbf{x})]$, and $\left|\mathrm{P}_{\mathrm{k}}\right|=\frac{k}{100} \cdot n$ is the cardinality of the set $P_{k}$. The outlier values are searched within $10 \%$ of the borderline cases, which are defined from the $P_{5}$ and $P_{95}$ percentiles as follows:

$$
x_{\text {outlier }} \in\{\mathrm{P} 5 \bigcup\{\mathrm{P} 100-\mathrm{P} 95\}\}
$$

The outliers, the outcome of the described procedure, are the candidate critical points (milestones) in the long-term history of the TAN. Based on their frequency in the overall analysis, the candidate milestones are further filtered to divide the long-term history of Turkish aviation into candidate time periods. In the second step of the methodological framework, these candidate time periods are submitted to a literature evaluation in order to determine whether they have real-world meaning for Turkish aviation history. To this end, a literature review is conducted to detect the historical events recorded simultaneously with the reference time of the candidate milestones, and correspondences are identified. In the third step, the two previous steps (TSA estimation of time periods and literature evaluation) are jointly considered to validate the historical time periods of the aviation sector in Turkey, which produces verified time periods in the long-term history of the TAN. Finally, in the fourth step, the overall approach is evaluated and discussed, and conclusions are drawn.

\section{Results and Discussion}

\section{Time-series analysis at NS level}

An ADF (Shumway-Stoffer 2017) for a lag of three periods $\left(t_{0}, t_{1}\right.$, and $\left.t_{2}\right)$ is performed to examine whether the available data belong to a stationary time series. The results (see Table 1) indicate that this test fails to reject the null hypothesis of a unit root against the autoregressive alternative. Thus, the TAN time series is not a stationary verification of the initial visual evaluation of the raw time-series data.

Table 1

\section{Results of ADF test on TAN stationarity}

\begin{tabular}{l|r|r|r}
\hline \multirow{2}{*}{} & \multicolumn{3}{|c}{$\operatorname{Lag}(p)$} \\
\cline { 2 - 4 } & \multicolumn{1}{|c}{$\mathrm{t}_{0}$} & $\mathrm{t}_{1}$ & \multicolumn{1}{c}{$\mathrm{t}_{2}$} \\
\hline $\mathrm{h}^{\mathrm{a}} \mathrm{0}$ & 0 & 0 & 0 \\
$p$-value & 0.9990 & 0.9990 & 0.9990 \\
stat & 3.1188 & 2.5907 & 2.2653 \\
$c$-value & -3.4921 & -3.4934 & -3.4946
\end{tabular}

a) $\mathrm{h}=0$ indicates failure to reject the unit-root null (non-stationary). $\mathrm{h}=1$ indicates rejection of the unit-root null in favour of alternative model (stationary).

Regional Statistics, Vol. 10. No. 2. 2020: 117-141; DOI: 10.15196/RS100204 
Observing the raw time-series data in Figure 3 reveals four reference periods based on a numerical scale. These periods are defined by the years 1969, 1991, and 2004. The diagram shows that, before 1969, the evolution of Turkey's air traffic appears almost stationary; after this year, an increasing trend begins. Starting in 1991, the slope of the increase grows and then rises steeply from 2004. Regarding scale, prior to 1969, air traffic averaged 1,012,217 passengers per year; then it averaged 6,079,715 passengers per year for $[1969,1990]$, almost six times greater than in the first period; $28,012,648$ passengers per year for [1991, 2003], almost eight times greater than in the second period; and 120,317,704 passengers per year after 2004, almost four times greater than in the third period.

Figure 3

Time periods derived from (raw) Turkish air passenger traffic data at NS level

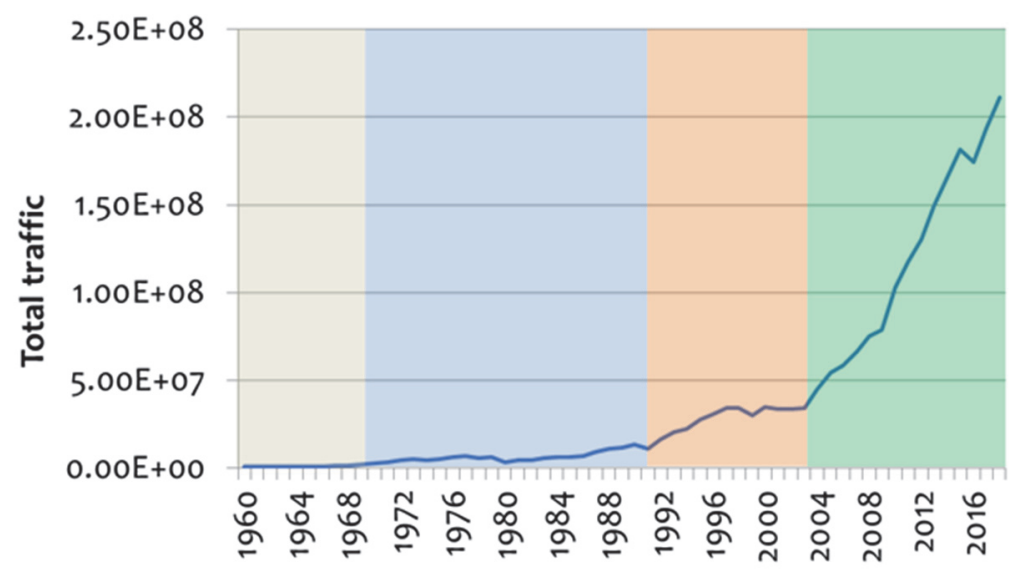

Note: based on numerical scale data.

The results derived from the TSA expressed in numerical values are shown in Figure 4 and those expressed in terms of signs are shown in Figure 5. 
The results derived from the TSA expressed in numerical values
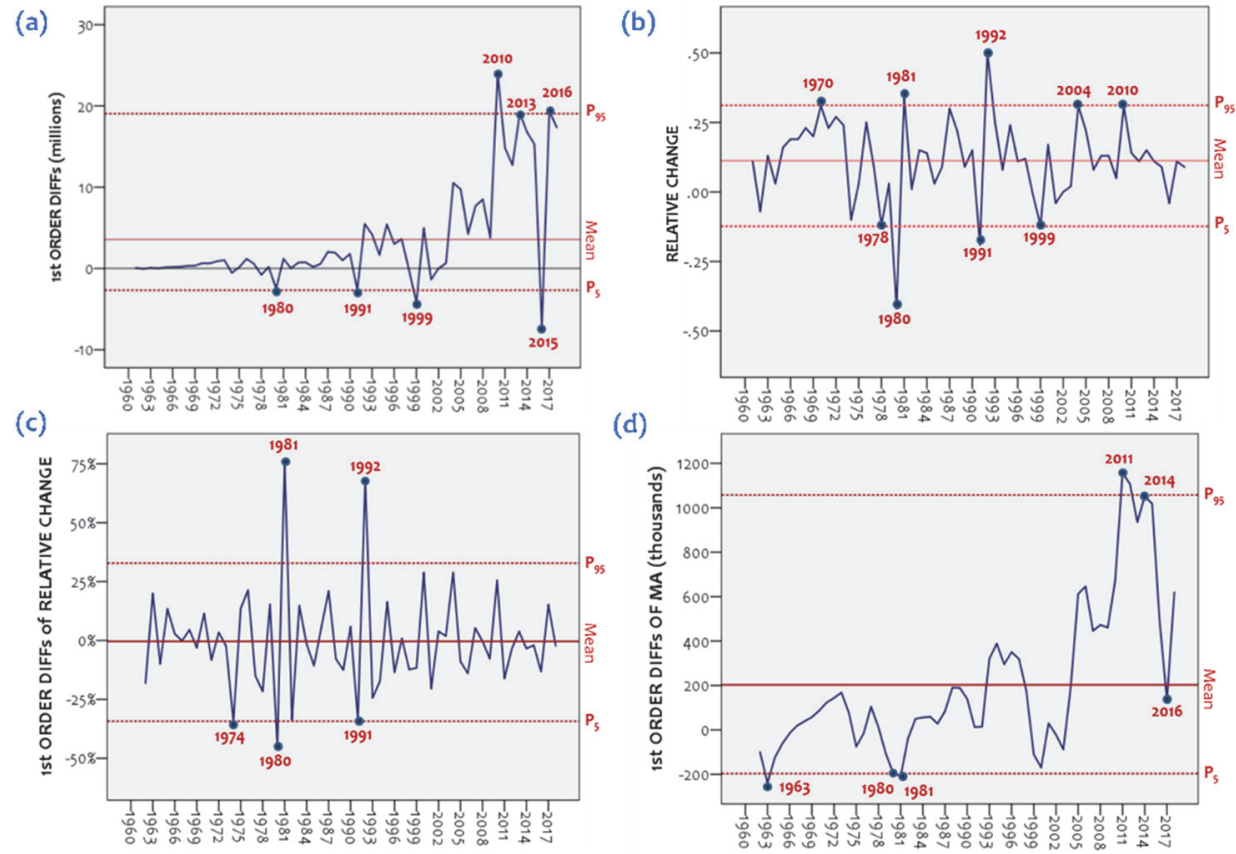

Notes: Outlier values exceeding the range $\left[\mathrm{P}_{5}, \mathrm{P}_{95}\right]$ between the $5^{\text {th }}\left(\mathrm{P}_{5}\right)$ and $95^{\text {th }}$ percentiles $\left(\mathrm{P}_{95}\right)$ for the distribution of (a) first-order differences, (b) relative changes, (c) first-order differences of relative changes, and (d) first-order differences of the moving average (MA), all of which are computed using time-series data of NS air passenger traffic in Turkey. These outliers suggest candidate milestones in the long-term history of Turkey's aviation sector.

The outliers produced by the TSA are the candidate milestones in the history of the TAN. We can observe outliers due to first-order differences $\Delta^{(1)} x_{t}$ (see Figure 4a) in 1980, 1991, 1999, 2010, 2013, 2015, and 2016; due to relative changes $\Delta_{R} x_{t}$ (see Figure 4b) in 1970, 1978, 1980, 1991, 1992, 1999, 2004, and 2010; due to first-order differences of relative changes $\Delta^{(1)}\left(\Delta_{R} x_{t}\right)$ (see Figure 4c) in 1974, 1980, 1981, 1991, and 1992; and due to first-order differences of the moving average $\Delta^{(1)}\left(M A\left(t_{n}\right)\right)$ (see Figure 4d) in 1963, 1980, 1981, 2011, 2014, and 2016. Next, the signum function analysis of the long-term history of TAN (see Figure 5) produces time periods composed of sequential years with the same sign. The signum function consideration of the first-order differences $\Delta \Delta^{(1)} x_{t}$ produces four discrete time periods with a positive sign: [1963, 1973], [1981, 1990], [1992, 1997], and [2002, 2014]. The signum function consideration of the relative changes $\Delta_{R} x_{t}$ also produces four discrete time periods with a positive sign: [1963, 1973], [1981, 1990], [1992, 1996], and [2003, 2015].

Regional Statistics, Vol. 10. No. 2. 2020: 117-141; DOI: 10.15196/RS100204 
The results derived from the TSA expressed in terms of signs
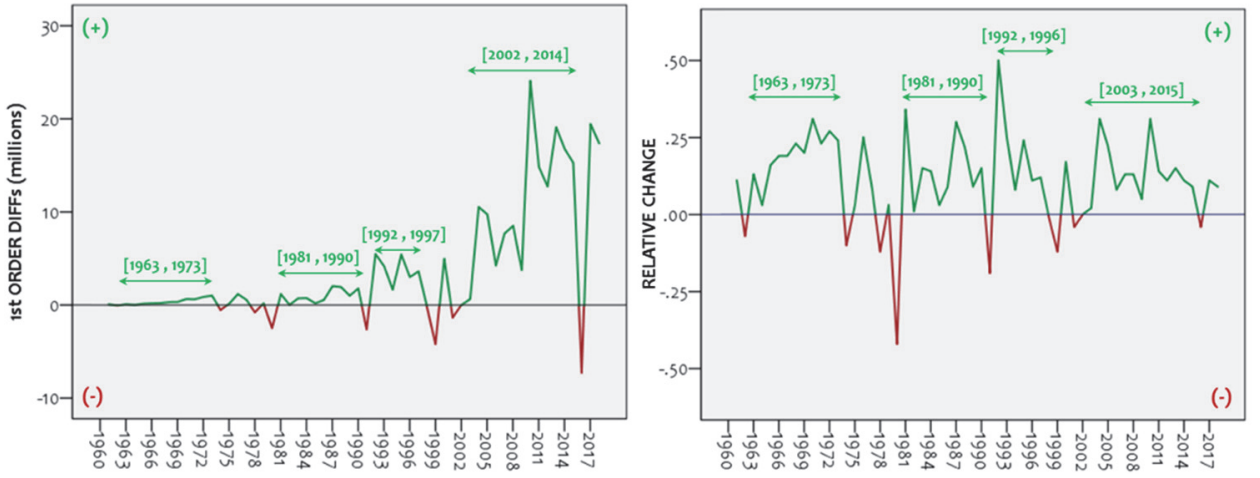

Notes: Time periods defined by the sign functions of first-order differences (left) and of relative changes (right) computed using time-series data of NS air passenger traffic in Turkey.

\section{Time-series analysis at RS level}

As in the NS analysis above, we examine the raw time-series data at the RS level. Their numerical scale enables us to identify five reference periods in the cluster configured by the 55 RS time-series diagrams (see Figure 6). These periods are defined by the years 1966, 1989, 2001, and 2004. For the period prior to 1966, air traffic averaged 14,743 annual passengers per airport. Afterwards, air traffic averaged 88,550 passengers per airport per year for $[1966,1988]$, almost six times greater than in the first period; 432,788 passengers per airport per year for [1989, 2000], almost five times greater than in the second period; 584,623 passengers per airport per year for [2001, 2003], comparable to the third period; and 2,076,780 passengers per airport per year after 2004, almost four times greater than in the third and fourth periods. The decay observed for [2001, 2003] concerns only the maximum outlier cases (airports) and not the majority of airports, since the average number of passengers was not affected. 
Time periods observed from (raw) Turkish air passenger traffic data at RS level

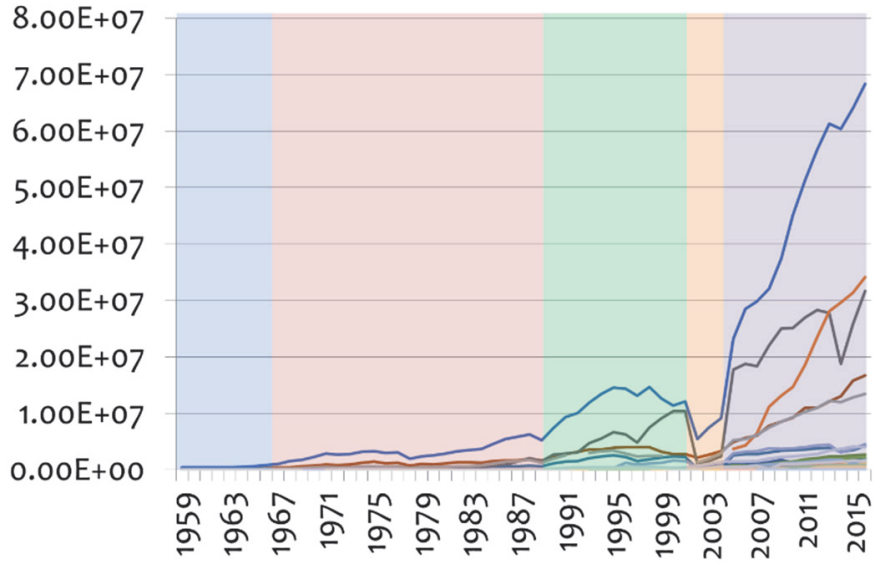

Note: based on the numerical scale.

We configure the time sequence (1959-2018) of the boxplots shown in Figure 7 to obtain a sharper picture of the time distribution of the regional data. In contrast to the previous consideration, we apply a log transformation to the vertical axis of the diagram. This approach allows us to configure the time periods in the history of regional TAN traffic based on the years wherein the whiskers of the boxplots exceed the $\mathrm{P}_{5}$ and $\mathrm{P}_{95}$ borderlines. We can observe that three time periods exceed the percentile borderlines: [1959, 1968], [1976, 1984], and [1991, 2017].

Diachronic distribution of airport network traffic for 1959-2018

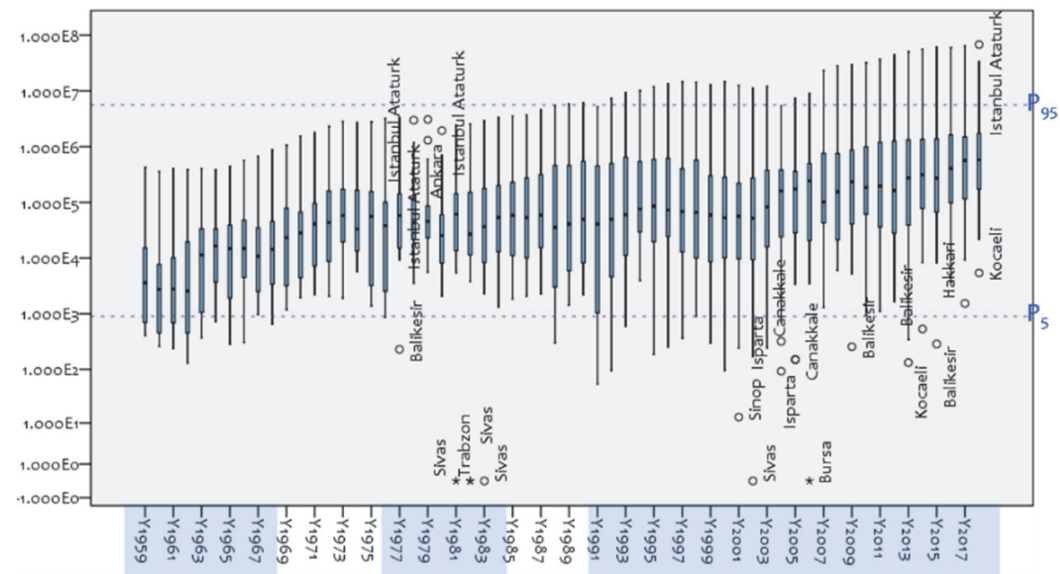

Notes: Boxplots computed using regional TAN data (airports). Periods with outlier values exceeding the interval $\left[\mathrm{P}_{5}, \mathrm{P}_{95}\right]$, computed using aggregate traffic data (for all available years), are shown within a coloured frame (vertical axis appears in log scale).

Regional Statistics, Vol. 10. No. 2. 2020: 117-141; DOI: 10.15196/RS100204 


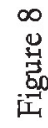
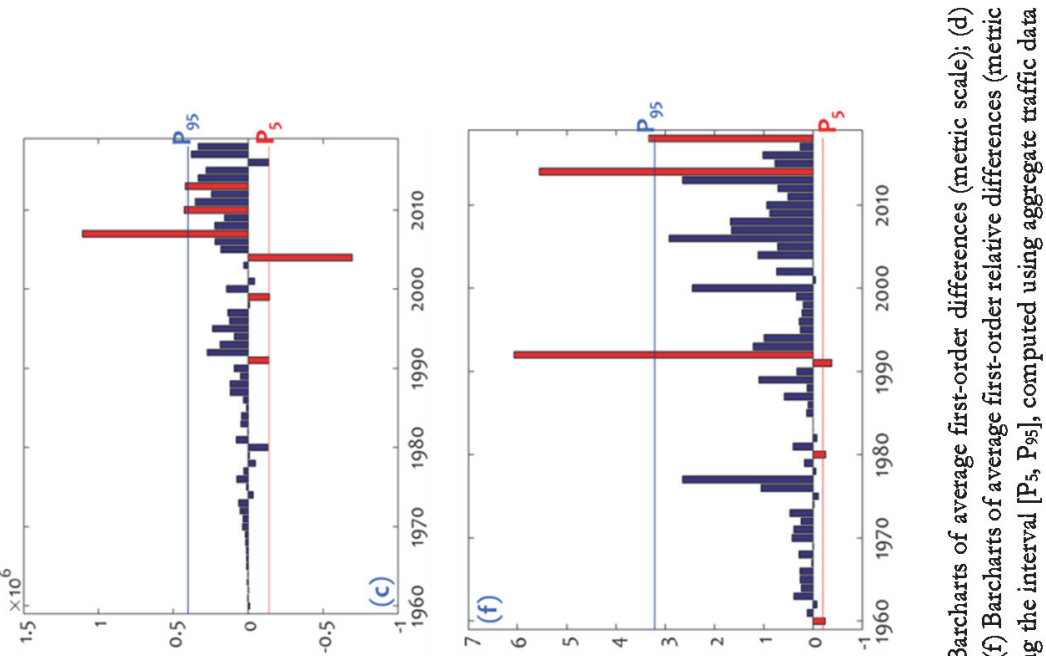

政
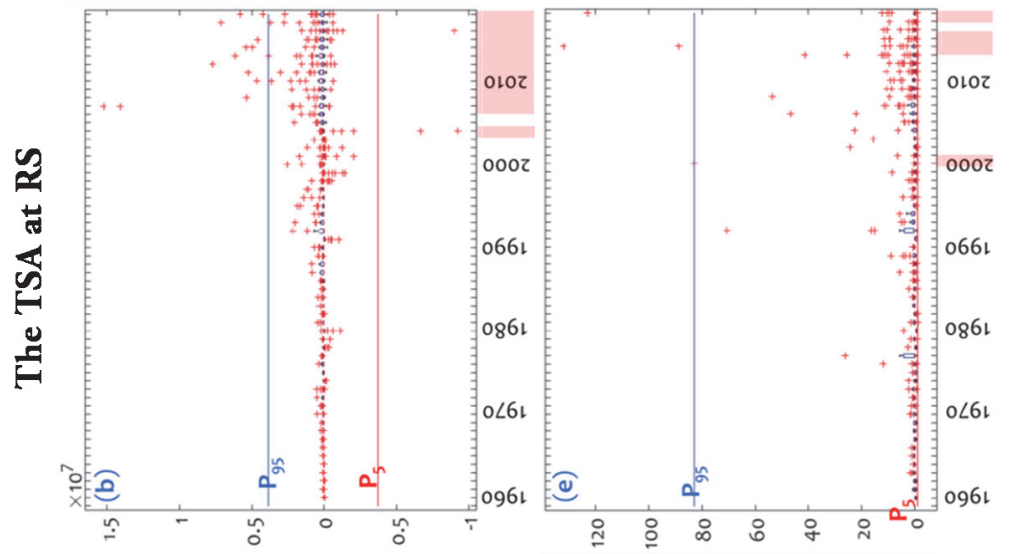

(e)

然

తึ

㗊焉

है

象

焉

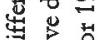

奇橤

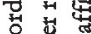

证

岁要 它

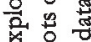

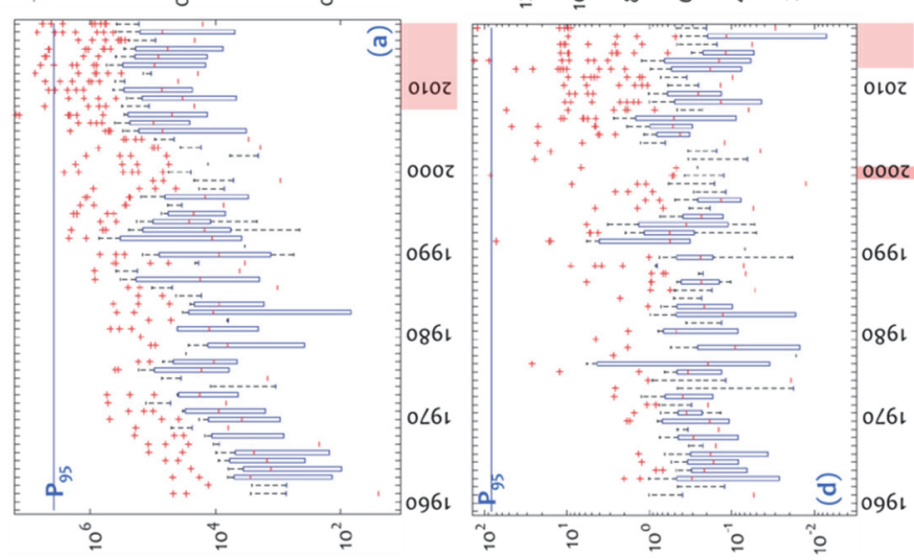

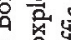

อิ

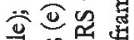

势亟

b. $\mathrm{H}$

胥

过要

起象

要要

式苛 矛

䓌言要

出总

诺

을 帝矛

它岁寻

ख

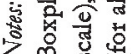

Regional Statistics, Vol. 10. No. 2. 2020: 117-141; DOI: 10.15196/RS100204 
Outlining the historical framework of the aviation sector in Turkey: A spatiotemporal approach

The TSA at RS is shown in Figure 8. The first-order differences in log (Figure 8a) and metric scales (Figure 8b) and on average in metric scale (Figure 8c) are shown, along with the first-order relative differences in log scale (Figure 8d), in metric scale (Figure 8e), and their averages in metric scale (Figure 8f). Candidate milestones are detected in 1980, 1990, 2004, and 2008.

\section{Configuration of time periods in TAN history}

\section{Estimation of candidate time periods}

Based on the previous TSA at the NS and RS levels, we configure the diagram shown in Figure 9 summarising the potential milestones in the TAN's long-term history. The frequency with which a case appears in this aggregate diagram is considered a measure of importance (i.e. a potential milestone). To facilitate the literature review, we reduce the data resolution by focusing on cases appearing more than once in this aggregate diagram. The cases of greatest importance $(\geq 4)$ are apparently more likely to suggest a historical TAN milestone.

Figure 9

\section{The configuration of candidate time periods in long-term TAN history}

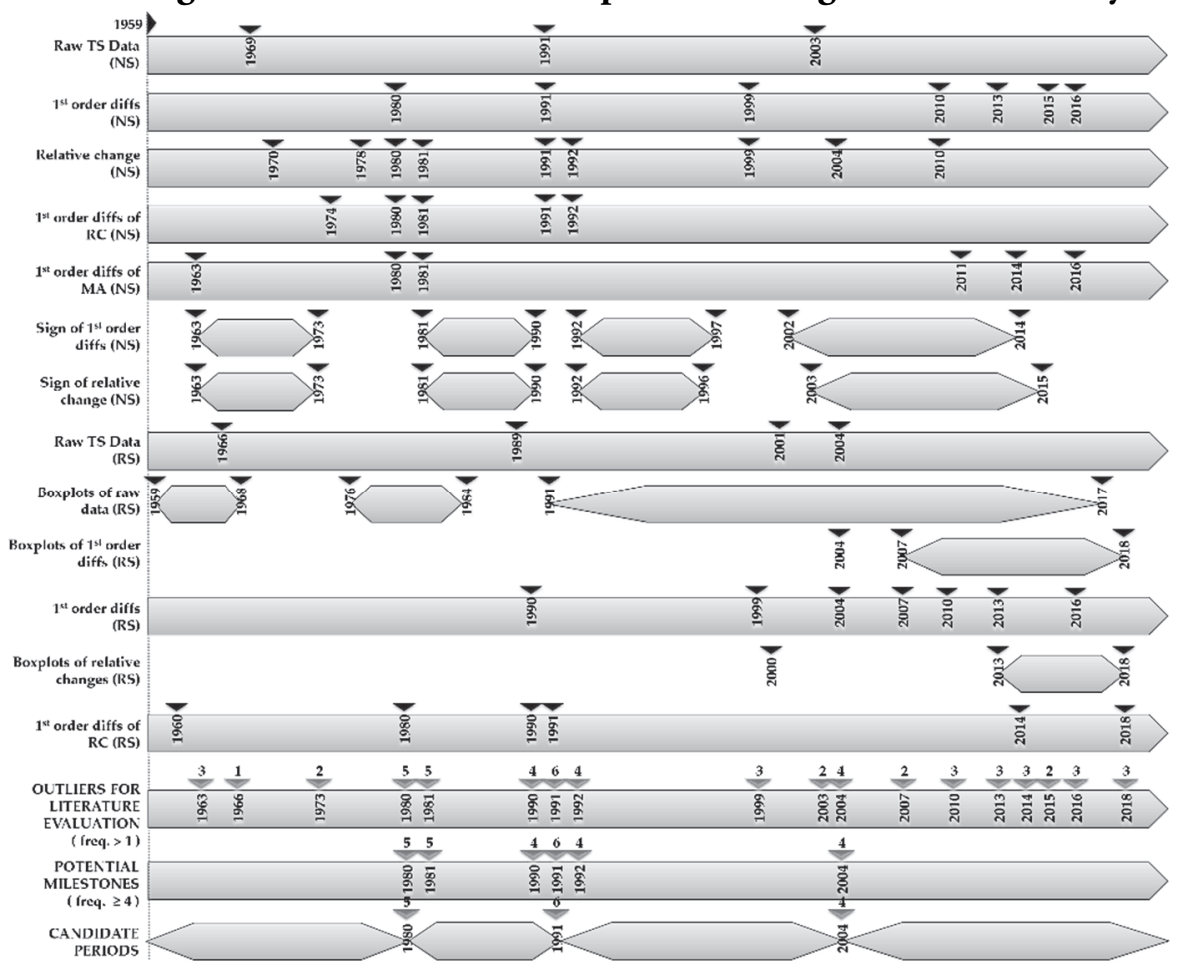

Note: The frequency with which a case appears in this aggregate diagram is considered a measure of importance (i.e. a potential milestone).

Regional Statistics, Vol. 10. No. 2. 2020: 117-141; DOI: 10.15196/RS100204 
The analysis shown in Figure 9 indicates that the potential milestones to be examined in the literature evaluation are in 1963, 1966, 1973, 1980, 1981, 1990, 1991, 1992, 1999, 2003, 2004, 2007, 2010, 2013, 2014, 2015, 2016, and 2018. The most important of these are 1980 (freq. = 5), 1981 (freq. = 5), 1990 (freq. = 4), 1991 (freq. = 6), 1992 (freq. = 4), and 2004 (freq. = 4). The literature on the history of Turkey's aviation sector is thus reviewed to investigate these potential milestone years.

\section{Literature evaluation}

The historical events concerning the TAN and their importance according to the TSA are summarised in Table 2 . The historical periods that dominated the history of the TAN are summarised in Table 3. We see that aviation activities in Turkey began with the construction of two hangars and a short runway in 1912 in Sefakoy, Istanbul (Bakirci 2012), an area close to Ataturk Airport. Aviation activities then developed in accordance with the environment and the priorities driven by the Second World War. THY, Turkey's flagship carrier, was established as a state-owned enterprise in 1933, and Istanbul Ataturk Airport was selected as its operational centre (Sarilgan 2016). The first civil flights operated between Istanbul and Ankara airports in 1933, with a capacity of five aircraft and 28 seats (Bakirci 2012). This route connected the old imperial capital city of Istanbul to Ankara, the new capital city. Located in central Turkey, Ankara was new and modern, while Istanbul was regarded as un-modern. Izmir and Adana airports were completed in 1939 (THY 2018). The geography of Turkey's airports and its air routes were expanded to the western (Mediterranean) parts of the country. In 1943, Van airport was added to the network (Bakirci 2012). The growth and development of Turkey's aviation sector accelerated amid the political and technological environments of the Second World War. Airports were constructed in Sivas, Erzurum, Malatya in eastern Turkey; Diyarbakir, Gaziantep, and Urfa in south-eastern Turkey; Konya and Kayseri in central Turkey; Antalya and Iskenderun in southern Turkey; Samsun in northern Turkey; and Bursa in western Turkey from 1945 to 1947 (THY 2018). These airports expanded the geography of the aviation sector beyond major cities (e.g. Istanbul, Ankara, Izmir) to include secondary regional hubs (Tasligil 2014).

After 1947, the capacity of the aviation sector increased in terms of both aircraft and seats, and Turkey's aviation activities expanded to the international level. In line with the Westernisation of the nation, Turkey's first international flight took place in 1947, between Ankara and Athens with a connection at Istanbul. In 1951, the TAN's international destinations increased to four (Athens, Rome, Frankfurt, and Vienna), the number of aircraft to 33, and the number of seats to 1,120 (THY 2018). The growth of the aviation sector continued in parallel with technological developments, decreasing oil prices, and increasing capital investments, leading to the emergence of new lines from Turkey to the Middle East and Europe (THY 2018). In 1963, flights from Turkey to the United States began, and new European destinations were

Regional Statistics, Vol. 10. No. 2. 2020: 117-141; DOI: 10.15196/RS100204 
included in the TAN (Orhan-Gerede 2013). Until the 1980s, Turkey's aviation sector was state-regulated and developed mainly through public investments. Several publicowned enterprises providing ground handling, catering services, and mechanical services were established in this period. The THY, airports, and supplementary services (e.g. ground handling, catering services, and mechanical services) were maintained as strict monopolies (Orhan-Gerede 2013).

After 1980, the Turkish economy was exposed to rapid and uncontrolled liberalisation (Pamuk 2014). These liberalisation policies meant that the state was no longer the sole regulator of the economy; rather, regulation occurs in accordance with the priorities of capital groups and the market (Boratav 2008). The Civil Aviation Law was issued in 1983, and many airline companies started operating in the aviation market without entry restrictions. With the help of free market-oriented deregulation and an increased number of TAN airports, 16 private airline companies were established between 1980 and 1990 (Battal-Kiraci 2015). However, six of these companies soon ceased operations (Cetin-Benk 2011, Kiraci 2018). In line with the increasing domestic and international demand, the number of airports in Turkey increased to 38 in this period (Bakirci 2012). The market liberalisation fostered demand for airlines, and the aviation sector developed rapidly. Domestic air ridership more than quadrupled between 1980 and 1990 (TUIK 2010, GDSAA 2018). However, the overwhelming majority of the flights were between the major airports in western Turkey. Flights to airports in northern, eastern, and southern Turkey were limited and seasonal. To overcome this problem, several regulations aimed at balancing the flight differential between the regional airports were implemented (Orhan-Gerede 2013). Any aviation company entering the Turkish market had to operate at least one flight to secondary airports.

After the 1990s, the TAN's liberalisation was interrupted by the protectionist measures taken in response to the national economic crises in 1988-1989, 1994, and 2001; the Gulf War in 1990, and the Asian Crisis in 1997 (Pamuk 2014, Battal-Kiraci 2015). Privatisation policies were applied to state aviation institutions in the late 1990s (Togan 2016). In this period, 18 new airline companies entered the market to meet both domestic and international demand. The total number of airline companies increased to 28. However, 19 of these companies exited the market between 1990 and 2000; high competition, poor market strategies, lack of experience, and high taxes led to their bankruptcy. Additionally, regulations were implemented by state aviation authorities in order to protect THY's market share. The 'THY Is First' strategy included provisions requiring new companies to operate only on lines that THY was not operating on or that THY could not service. These measures reduced the competitive power of emerging aviation companies (Orhan-Gerede 2013).

In 1989, Sun-Express joined in partnership with THY and Lufthansa to operate as a leisure airline providing charter flights between Turkey and Germany (Bakirci 2012). The main hub of the company was in Antalya, a major tourism destination in Turkey. In 1998, Antalya airport was expanded with a terminal constructed for

Regional Statistics, Vol. 10. No. 2. 2020: 117-141; DOI: 10.15196/RS100204 
international flights via public-private cooperation on a build-operate-transfer (BOT) model (Acar-Karabulak 2015). This was the first use of the BOT model for infrastructure investments in the aviation sector. Konya and Istanbul Sabiha Gokcen airports began operating in 2000 and 2001, respectively, and the total number of airports in Turkey had increased to 40 by 2003. Sabiha Gokcen Airport, completed in 2001, was Turkey's first privately operated airport (Bakirci 2012).

The privatisation of public Turkish aviation enterprises began in the 1990s. In this period, the nation's economy and its domestic and international aviation activities were affected by the 1988-1989 economic crisis and the Gulf War (Battal-Kiraci 2015). Ucak Servisi Anonim Sirketi (USAS), the public supplier for ground handling services and catering, became the first privatised public aviation company in Turkey. Togan (2016) stresses that $70 \%$ of the catering services were privatized in 1989, and the remaining $30 \%$ were privatized in 1993, additionally, $60 \%$ of the ground handling services were privatized in 1995 and the remaining 40\% were privatized in 1998. Turkey's economy also experienced several major milestones just before the 2000s; the Asian Crisis affected international flight demand in 1997, and catastrophic earthquakes and economic crises occurred in 1999 and 2001, respectively.

Starting in the 2000s, neo-liberalisation policies came to the fore, a process fostered by the neoliberal agenda being pursued across the world (Togan 2016). These processes have been particularly brutal in developing countries. The liberalisation program of the government led to crucial privatisation and deregulation measures like the privatisation of national refineries, industrial areas, and factories (Togan 2016). The government's motto has been 'Every Turkish citizen will board at least once' since the 2000s began. This period consists of three sub-periods (see Figures 5 and 6). The first sub-period covers 2000 to 2004; this can be considered a period of transition to a liberal market driven by the deregulation policies known as 'Dervis Policies', after the Minister of Economic Affairs who initiated the IMF liberalisation program. After 2002, this liberalisation program was fostered by the new government, which is still ruling Turkey (Türkan-Ozel 2019). In 2003, the aviation market was deregulated.

In this period, several old airports were restored to service, and new airports were constructed. The geography of the aviation sector was expanded to include all parts of the country, increasing demand for domestic flights between the peripheral small cities and the major airports (Orhan-Gerede 2013). The market deregulation accompanied by the increasing domestic demand attracted the attention of private companies. After 2003, several low-cost carriers servicing both domestic and international destinations entered the market with varying strategies. Legislation deregulating the market and eliminating the price advantages and privileges of THY were the main impetus for this process (Tasligil 2014).

Regional Statistics, Vol. 10. No. 2. 2020: 117-141; DOI: 10.15196/RS100204 
Summary of historical TAN events and their importance according to TSA

\begin{tabular}{|c|c|c|c|}
\hline Year & $\begin{array}{c}\text { TSA } \\
\text { Importance }\end{array}$ & Related historical events & References \\
\hline 1912 & - & $\begin{array}{l}\text { Construction of two hangars and a short runway in Sefakoy, } \\
\text { Istanbul and then in Esenboga, Ankara. }\end{array}$ & Bakirci (2012) \\
\hline 1933 & - & $\begin{array}{l}\text { Establishment of THY; THY starts operating from Istanbul } \\
\text { Ataturk to Ankara Esenboga airport }\end{array}$ & $\begin{array}{l}\text { Bakirci (2012) } \\
\text { Sarilgan (2016) }\end{array}$ \\
\hline 1939 & - & Construction of Izmir and Adana airports & THY (2018) \\
\hline 1943 & - & Construction of Van airport & Bakirci (2012) \\
\hline $\begin{array}{l}1945- \\
1947\end{array}$ & - & $\begin{array}{l}\text { Construction of new airports in all regions (LTAR, LTCE, } \\
\text { LTAO, LTCC, LTAJ, Urfa, LTAN, LTAM, LTAI, } \\
\text { Iskenderun, LTFH, LTBE) }\end{array}$ & THY (2018) \\
\hline 1951 & - & $\begin{array}{l}\text { Increase of international destinations (Athens, Roma, } \\
\text { Frankfurt, and Vienna) }\end{array}$ & THY (2018) \\
\hline 1963 & 3 & $\begin{array}{l}\text { First flights from Turkey to the U.S.; New European } \\
\text { destinations started }\end{array}$ & $\begin{array}{l}\text { Orhan-Gerede } \\
(2013)\end{array}$ \\
\hline 1973 & 2 & Establishment of the aircraft industry in Kayseri, Turkey & Eriksson (2016) \\
\hline 1980 & 5 & Military coup & Pamuk (2014) \\
\hline 1981 & 5 & Trade liberalisation program & Pamuk (2014) \\
\hline 1983 & - & Issue of Civil Aviation Law & Togan (2016) \\
\hline 1989 & - & Sun-Express partners with THY & Bakirci (2012) \\
\hline 1990 & 4 & Gulf War, global economic crises & $\begin{array}{l}\text { Pamuk (2014); } \\
\text { Battal-Kiraci (2015); }\end{array}$ \\
\hline 1991 & 6 & Privatisation of the state-based institutions & THY (2018) \\
\hline 1992 & 4 & End of Gulf War & $\begin{array}{l}\text { Korul-Kuçukonal } \\
(2003)\end{array}$ \\
\hline 1999 & 3 & National economic crises & Pamuk (2014) \\
\hline 2003 & 2 & $\begin{array}{l}\text { Major barriers for market entry were eliminated; } \\
\text { total number of airports increased to } 40\end{array}$ & $\begin{array}{l}\text { Bakirci }(2012) \text {; den } \\
\text { Hartigh-Kucukonal } \\
(2012)\end{array}$ \\
\hline 2004 & 4 & Deregulation of aviation market & $\begin{array}{l}\text { Orhan-Gerede } \\
(2013)\end{array}$ \\
\hline 2006 & - & $\begin{array}{l}\text { New international terminal at Izmir's Adnan Menderes } \\
\text { Airport opened; many airports reopened }\end{array}$ & THY (2018) \\
\hline 2007 & 2 & $\begin{array}{l}\text { New airports (LTAS, LTCS, LTAK, LTAO) entered TAN, } \\
\text { many airports reopened }\end{array}$ & THY (2018) \\
\hline 2008 & - & THY joined Star Alliance; new airports (LTAP) entered TAN & THY (2018) \\
\hline 2010 & 3 & $\begin{array}{l}\text { New airports (LTFG, LTFK) entered TAN; major } \\
\text { improvements to Balıkesir Koca Seyit Airport }\end{array}$ & THY (2018) \\
\hline 2011 & 1 & New airports (LTBQ) entered TAN & THY (2018) \\
\hline 2012 & - & New airports (LTBZ, LTCT) entered TAN & THY (2018) \\
\hline 2013 & 3 & $\begin{array}{l}\text { New airports (LTCV) entered TAN; major improvements to } \\
\text { Kastamonu Airport }\end{array}$ & THY (2018) \\
\hline 2014 & 3 & $\begin{array}{l}\text { New domestic terminal at Izmir's Adnan Menderes Airport } \\
\text { opened }\end{array}$ & THY (2018) \\
\hline 2015 & 2 & $\begin{array}{l}\text { Subsidies for promoting lines between secondary and major } \\
\text { airports }\end{array}$ & DGCA (2014) \\
\hline 2016 & 3 & $\begin{array}{l}\text { Holiday bans from Russian government in response to the } \\
\text { war aircraft crisis }\end{array}$ & Ersen (2017) \\
\hline 2018 & 3 & Istanbul Grand Airport & THY (2018) \\
\hline
\end{tabular}

Regional Statistics, Vol. 10. No. 2. 2020: 117-141; DOI: 10.15196/RS100204 
The second sub-period covers 2004 to 2008. These were the golden years for the growth of the aviation sector in Turkey in terms of both domestic and international passengers. THY increased its capacity substantially and started to focus on international operations through a strategy of expanding to all continents with the help of technological and political changes in the global aviation sector (OrhanGerede 2013). The company managed to meet the high share of domestic demand until the 2008 creation of Anadolujet (Sarilgan 2016), a low-cost carrier and THY subsidiary established to help meet domestic demand (THY 2018). THY entered into partnership with the Star Alliance in 2008 in order to service new destinations in the global market. This was perhaps the most significant development in the sector. The passenger volume of domestic flights almost quintupled between 2003 and 2010 (see Figure 3).

The third sub-period ranges from 2008 to the present. As Figure 3 shows, the growth rates in the number of both domestic and international passengers were interrupted by the increases in oil prices and the economic and political environments created by the 2008 global crises (Togan 2016). After 2010, the growth of Turkey's aviation market boomed due to new developments in the sector, in line with the growth of the Turkish economy (Duran-Erdem 2017, Shinnar-Zamantili 2019). The aviation sector was supported by budgetary allocations as well as the BOT model of public-private partnerships. Two subsidies were provided by the government to increase and enhance the connections between secondary and major airports in 2013 and 2015 (DGCA 2014). This growth pattern was interrupted by the Syrian war and the political tensions between Turkey and Russia in 2016, which affected the tourism sector and international flights (see Figure 3). Nevertheless, the volume of domestic passengers continued to grow significantly.

Domestic flights had departed from seven centre hubs (Ataturk, Sabiha Gokcen, Izmir, Adana, Trabzon, and Antalya) to 49 airports and from two centre hubs (Ataturk and Ankara) to 26 airports. The BOT model was used frequently for the renovation, construction, and expansion of the airports. Zonguldak, Gazipasa, and Aydin airports were constructed via the BOT model, and are to be operated for 20 years by the private sector. The terminal buildings of Ataturk, Izmir, Antalya, Milas-Bodrum, and Dalaman airports are being rented for varying durations, from 15 years to 26 years. Under the BOT model, airport terminal construction and operations were transferred to the private sector (Acar-Karakulak 2015, Tasligil 2014).

Subsidies were used to increase connections between smaller and major airports, promoting new flight lines in 2013 and 2015. Accordingly, the number of domestic lines from the seven centre hubs increased to 52 by 2013 (DGCA 2014). Five regulations were established in 2013. The first stipulated the minimum number of flights that must be provided by companies assigned to new lines: The number of weekly flights cannot be fewer than three during the summer and two during the winter for each line. The second requirement concerns the date on which flights

Regional Statistics, Vol. 10. No. 2. 2020: 117-141; DOI: 10.15196/RS100204 
begin: Flights had to start in the summer of 2013. The third requirement concerns the duration of the allocation of the lines: If a company was assigned a line, no other company was allowed to fly on it for two years. The fourth requirement was designed to promote new domestic lines through international lines: If a company had started adequate flights in new domestic lines, priority would be given to servicing international lines. If a domestic line was cancelled, the allocated international line would also be cancelled. The last requirement regulated the rights of passengers on new lines: Any company found to be using its current position against passengers or charging excessive prices would be taken off its line (DGCA 2014).

Table 3

\section{Summary of historical TAN periods}

\begin{tabular}{|c|c|c|c|c|}
\hline Denomination & Pre-1980 & 1980-1991 & 1991-2004 & After 2004 \\
\hline Period name & $\begin{array}{l}\text { State-dominated } \\
\text { period }\end{array}$ & $\begin{array}{l}\text { Liberalising transition } \\
\text { period }\end{array}$ & $\begin{array}{l}\text { 'State-regulation } \\
\text { revisited' period }\end{array}$ & $\begin{array}{l}\text { Liberalised market } \\
\text { period }\end{array}$ \\
\hline Contextual & $\begin{array}{l}\text { Import- } \\
\text { substitution } \\
\text { industrialisation } \\
\text { based closed } \\
\text { economy }\end{array}$ & $\begin{array}{l}\text { Liberalisation; } \\
\text { Opening up to } \\
\text { international trade, } \\
\text { uncontrolled trade } \\
\text { liberalisation }\end{array}$ & $\begin{array}{l}\text { Liberalisation; } \\
\text { Opening up to } \\
\text { international trade, } \\
\text { uncontrolled trade } \\
\text { liberalisation }\end{array}$ & $\begin{array}{l}\text { Fast liberalisation, } \\
\text { Privatisation of the } \\
\text { public-owned enter- } \\
\text { prises, integration } \\
\text { with European Union }\end{array}$ \\
\hline $\begin{array}{l}\text { Socio- } \\
\text { economic }\end{array}$ & $\begin{array}{l}\text { Market monopoly } \\
\text { of THY, state } \\
\text { dominance }\end{array}$ & $\begin{array}{l}\text { Uncontrolled } \\
\text { deregulation of } \\
\text { aviation market, } \\
\text { THY-first privileges, } \\
\text { institutions have } \\
\text { strong regulation } \\
\text { power }\end{array}$ & \begin{tabular}{|l|} 
Uncontrolled \\
deregulation of \\
aviation market, new \\
regulations for saving \\
the position of THY \\
in the market
\end{tabular} & $\begin{array}{l}\text { Deregulation of the } \\
\text { market, emergence of } \\
\text { new low-cost-carrier } \\
\text { firms in the market }\end{array}$ \\
\hline $\begin{array}{l}\text { Market } \\
\text { players }\end{array}$ & THY & $\begin{array}{l}\text { THY and } 27 \text { new } \\
\text { companies entered } \\
\text { market; } 19 \text { of these } \\
\text { declared bankruptcy }\end{array}$ & $\begin{array}{l}\text { THY, } 8 \text { of the } \\
\text { companies declared } \\
\text { bankruptcy }\end{array}$ & $\begin{array}{l}\text { THY, Pegasus, } \\
\text { Sunexpress, } \\
\text { AnadoluJet, Borajet, } \\
\text { Izair }\end{array}$ \\
\hline Regulations & $\begin{array}{l}\text { Strong regula- } \\
\text { tion/control of } \\
\text { state and state- } \\
\text { owned institu- } \\
\text { tions, airports } \\
\text { operated by state- } \\
\text { owned institutions } \\
\end{array}$ & $\begin{array}{l}\text { Deregulated market, } \\
\text { state-owned institu- } \\
\text { tions control the } \\
\text { airports and market }\end{array}$ & \begin{tabular}{|l|} 
State-regulation \\
revisited, public \\
offering of $\% 1$ share \\
of THY, privatisation \\
of ground and \\
catering services,
\end{tabular} & $\begin{array}{l}\text { Free market environ- } \\
\text { ment, public-private } \\
\text { partnership for const- } \\
\text { ruction of airports, } \\
\text { airports operated by } \\
\text { private companies }\end{array}$ \\
\hline $\begin{array}{l}\text { Regional } \\
\text { airports }\end{array}$ & $\begin{array}{l}\text { Istanbul Atatürk } \\
\text { and Ankara }\end{array}$ & $\begin{array}{l}\text { Istanbul Atatürk, } \\
\text { Ankara and Izmir }\end{array}$ & $\begin{array}{l}\text { Istanbul Atatürk, } \\
\text { Ankara, Izmir, } \\
\text { Antalya }\end{array}$ & $\begin{array}{l}\text { Istanbul Grand, } \\
\text { Istanbul Sabiha } \\
\text { Gökçen, Ankara, } \\
\text { Izmir, Antalya, } \\
\text { Trabzon, Samsun, } \\
\text { Kayseri }\end{array}$ \\
\hline
\end{tabular}

The regulations in the 2015 legislation are similar to those in the 2013 legislation. However, the second and fourth regulations in 2013 were changed in the 2015 version (DGCA 2015). The 2015 version set June 1, 2015 as the start date for flight service;

Regional Statistics, Vol. 10. No. 2. 2020: 117-141; DOI: 10.15196/RS100204 
failure to start on that date would lead to allocation cancellation. Moreover, the 2015 version made provisions for both the cancellation and suspension of domestic flights. The 2015 Circular on Promoting New Flight Lines has led to new lines between major airports and secondary and small airports (DGCA 2015).

Turkey has been a very attractive destination for Russian and European tourists, especially during the sea-sand-sun tourism period in 2010 when visas were mutually lifted for the citizens of Turkey and Russia. However, the unstable and unpredictable environment caused by the Syrian war (which started in 2011 and turned into an international crisis in 2015), high volumes of refugees escaping ISIS violence in 2015, a failed coup attempt in 2016, and the tension between Turkey and Russia following the shooting down of a Russian warplane near Turkey's Syrian border in 2016 have affected Turkey's tourism sector and air passenger volume substantially (Ersen 2017). The failed coup attempt in 2016 led to an unstable economic environment that severely damaged Turkey's aviation sector, as well as other economic sectors. For example, Borajet, servicing smaller airports via a regional aviation strategy, exited the market in 2017 (DGCA 2017).

However, Turkey's aviation sector is growing fast, and the demand for new fleets, airports, and ground services are increasing daily along with technological developments. This has caused a need for a new airport. Istanbul Airport, the city's third airport and projected to be the largest in the world, is being constructed in the northern part (the European part) of the city in four phases. The first phase began in 2019 after an almost two-year delay. When Istanbul Airport is completed, it is expected to serve over 200 million passengers annually. Istanbul Airport is also being constructed through the BOT model under a state guarantee. Ataturk Airport is now closed.

\section{Conclusions}

Turkey's aviation sector has transitioned from a state-dominated structure to a liberalised market. This transition has been remarkable, and its geographical and historical mechanisms and patterns are worth analysing. This study's time-series analyses reveal the existence of four main developmental periods based on market dynamics, aviation policies, and regulations.

The state-regulated period is the longest of the four. It covers Turkey's initial aviation-based investments, such as those for airport construction and ground services. In this period, Turkish aviation activities were controlled solely by stateowned enterprises, institutions, and organisations - consistent with Turkey's overall economy. The liberal transition period (1980-1990) started with the military coup of 1980, which led to a major change in Turkey's economic environment, and this uncontrolled liberalisation period continued till to the 1990 Gulf War. The state's control over the economy decreased due to the new liberalisation programs, which

Regional Statistics, Vol. 10. No. 2. 2020: 117-141; DOI: 10.15196/RS100204 
were mainly based on free market principles. The aviation sector was also liberalised in 1983. New companies started providing aviation services on both domestic and international lines by competing with THY. During the Gulf War, new regulations were implemented to protect THY's market share and position. This began a new period of state regulation. This period starts with the Gulf War and ends with the new neoliberal agenda implemented in 2003 by the government that has been ruling the country since 2002. This liberalised market period starts with the deregulation of the aviation market. In this period, new low-cost aviation companies entered the market, and new airports were constructed. The aviation market enjoyed a boom due to increased demand for air passenger services. Istanbul Airport, considered the largest airport in the world, opened in 2018.

Though state regulation and control still play direct and indirect roles in Turkey's aviation sector, the sector was deregulated consistent with the neo-liberalisation of the national economy. The aviation sector boomed after the 2003 deregulation, but wide disparities persist across the TAN. Most major airports are located in the major cities, whereas there are few airports in the rest of the country.

This study showed that milestones in the history of Turkey's aviation sector can be identified via time-series analysis using simple and easily accessible data. The results reveal that the periods derived through the time-series analyses are consistent with the major changes discussed in the literature. The main drawback of this study is that, due to the unavailability of data regarding passenger traffic between airport pairs, we cannot measure how Turkey's deregulation and regulation policies affected the spatial configuration of the TAN. This issue should be addressed in future research.

\section{Acknowledgments}

The authors wish to thank two anonymous referees and the editor for their comments. We also wish to thank Associate Professor Muzaffer Bakirci for providing his annual passenger dataset at the regional level and Mrs. Duygu Buyukcebeci, from the TURKSTAT Izmir office, for her help in filling the gaps in the datasets. All remaining errors are ours.

\section{REFERENCES}

ACAR, A. Z.-KARABULAK, S. (2015): Competition between full-service network carriers and low-cost carriers in the Turkish Airline market Procedia-Social and Behavioral Sciences 207: 642-651. https://doi.org/10.1016/j.sbspro.2015.10.134

AnAZ, N.-Akman, E. (2017): Turkey's Soft Power Capacity: Geopolitics of Aviation and Turkish Airlines The Arab World Geographer 20 (4): 303-316. https://doi.org/10.5555/1480-6800.20.4.303

BAKIRCI, M. (2012): Ulasim cografyasi acisindan Turkiye'de hava yolu ulasiminin tarihsel gelisimi ve mevcut yapisi Marmara Cografya Dergisi Sayi 25: Ocak - 2012: 340-377.

Regional Statistics, Vol. 10. No. 2. 2020: 117-141; DOI: 10.15196/RS100204 
BARretT, S. D. (2000): Airport competition in the deregulated European aviation market Journal of Air Transport Management 6 (1): 13-27. https://doi.org/10.1016/S0969-6997(99)00018-6

BATTAL, U.-KIRACI, K. (2015): Bankruptcies and Their Causes in the Turkish Airline Industry The International Journal of Transport \& Logistics 15 (1): 1-11.

BÉRES, A.-JABLONSZKY, G.-LAPOSA, T.-NYIKOS, G. (2019): Spatial econometrics: transport infrastructure development and real estate values in Budapest Regional Statistics 9 (2): 1-17. https://doi.org/10.15196/RS090202

BORATAV, K. (2008): Turkiye iktisat taribi, 1908-2007. Imge kitabevi, Ankara.

Box, G.-Jenkins, G. M.-REInsEL, G. C.-LJUnG, G. M. (2015): Time series analysis: forecasting and control John Wiley \& Sons, New Jersey.

BRUfF, I. (2011): Overcoming the state/market dichotomy. In: SHIELDS, S.-BRUfF, I.Macartney, H.: Critical International Political Economy pp. 80-98., Palgrave Macmillan, London.

BUTTON, K. (1989): The deregulation of US interstate aviation: an assessment of causes and consequences (part 1) Transport Reviews 9 (2): 99-118. https://doi.org/10.1080/01441648908716714

BUTTON, K. (1996): Liberalizing European aviation: is there an empty core problem? Journal of Transport Economics and Policy 30 (3): 275-291.

CETIN, T.-BENK, S. (2011): Regulation, deregulation, and competition in the Turkish airline industry. In: ÇETIN, T.-OĞUZ, F. (eds.): The Political Economy of Regulation in Turkey pp. 193-214., Springer, New York.

DAS, S. (1994): Time series analysis Princeton University Press, New Jersey.

Den Hartigh, E.-KuCUKOnAL, H. (2012): The Turkish aviation system and the strategy of Turkish Airlines In: CuRRAN, R. et al. (eds.): Air Transport and Operations:

Proceedings of the Third International Air Transport and Operations Symposium 2012 pp. 231-245., IOS Press, Amsterdam.

Duran, H. E.-ERDEM, U. (2017): Regional inequality and international trade in Turkey: A dynamic spatial panel approach $A \mid Z$ ITU Journal of the Faculty of Architecture 14 (3): 25-39. https://doi.org/10.5505/itujfa.2017.24633

Eraydin, A. (2006): Degisen Mekan Mekansal Sureclere Iliskin Tartisma ve Arastirmalara Toplu Bakis: 1923-2003 Dost Kitabevi, Ankara.

Erdem, U.-Mert Cubukcu, K.-Tsiotas, D. (2019): Mapping the topology of the air transport network in Turkey. Environment and Planning A: Economy and Space, $0308518 X 19848753$.

ERIKSSON, S. (2016): Newly industrialising economies and the aircraft industry: economic and industrial policy views in Asia. In: ERIKSSON, S.-STEENHUIS, H. J. (eds.): The Global Commercial Aviation Industry pp. 231-296., Routledge, London. https://doi.org/10.4324/9780203582022

ERSEN, E. (2017): Evaluating the Fighter Jet Crisis in Turkish-Russian Relations Insight Turkey 19 (4): 85-104. https://doi.org/10.25253/99.2017194.06

Friedman, M. (2009): Capitalism and Freedom University of Chicago Press, Chicago.

GDSAAT (General Directorate of State Airports Authority of Turkey - 2018): Annual next and previous airports pairs of domestic flights, passengers, and cargo traffic GDSAAT Publication, Ankara, Turkey.

Regional Statistics, Vol. 10. No. 2. 2020: 117-141; DOI: 10.15196/RS100204 
Georgieva, A. D.-Duzgun, M.-Tanyas, M. (2015): The Importance of Istanbul Grand Airport (Iga) for Turkey and Its Influence on Widely Regional Air Traffic Around Research in Logistics \& Production 5 (3): 239-254.

GEREDE, E. (2015): Havayolu tasimaciligi ve ekonomik duzenlemeler teori ve Turkiye uygulamasi Art Ofset Matbaacilik, Ankara.

HoOper, P. (1998): Airline competition and deregulation in developed and developing country contexts -Australia and India Journal of Transport Geography 6 (2): 105-116. https://doi.org/10.1016/S0966-6923(98)00004-0

HudSON, R. S.-GREGORIOU, A. (2015): Calculating and comparing security returns is harder than you think: A comparison between logarithmic and simple returns International Review of Financial Analysis 38: 151-162. https://doi.org/10.1016/j.irfa.2014.10.008

Karaevli, A.-Yurtoglu, B. B (2018): Founding family effects on business group growth: Longitudinal evidence from Turkey (1925-2012) Long Range Planning 51 (6): 831-864. https://doi.org/10.1016/j.lrp.2017.08.003

KIRACI, K. (2018): Analysis of the Determinant Factors of the Historical Development of Air Transport: An Empirical Application to Turkey Studies in Business and Economics 13 (3): 74-90. https://doi.org/10.2478/sbe-2018-0036

Korul, V.-Kuçukonal, H. (2003): Türk Sivil Havacilik Sisteminin Yapisal Analizi Ege Akademik Bakus Dergisi 3 (1): 24-38.

Logothetis, M.-MiYOSHI, C. (2018): Network performance and competitive impact of the single hub-A case study on Turkish Airlines and Emirates Journal of Air Transport Management 69: 215-223. https://doi.org/10.1016/j.jairtraman.2016.10.003

Lucio, M. M.-Turnbull, P.-Blyton, P.-McGurk, J. (2001): Using regulation: An international comparative study of the civil aviation industry in Britain and Spain European Journal of Industrial Relations 7 (1): 49-70. https://doi.org/10.1177/095968010171004

ORHAN, G.-GEREDE, E. (2013): A study of the strategic responses of Turkish airline companies to the deregulation in Turkey Journal of Management Research 5 (4): 34-63. https://doi.org/10.5296/jmr.v5i4.4201

Palley, T. I. (2005): From Keynesianism to neoliberalism: Shifting paradigms in economics Neoliberalism: A critical reader, 20-29.

PAMUK, S. (2014): Turkiye'nin 200 yillik iktisadi taribi: buyume, kurumlar ve bolusum Turkiye Is Bankasi Kultur Yayinlari, Istanbul.

Polyani, K. (1944): The great transformation Rinehart, New York.

Polyzos, S. (2019): Regional Development, $2^{\text {nd }}$ Edition, Kritiki Publications, Athens, Greece.

SARILGAN, A. E. (2016): Impact of Low-Cost Carriers on Turkish Tourism Industry International Journal of Academic Research in Business and Social Sciences 6 (4): 176-188. https://doi.org/10.6007/IJARBSS/v6-i4/2088

SElCUK, O. (2013): Turkish Airlines: Turkey's soft power tool in the Middle East Akademik Ortadogu 7 (2): 175-199.

SHINNAR, R. S.-ZAMANTILI NAYIR, D. (2019): Immigrant Entrepreneurship in an Emerging Economy: The Case of Turkey Journal of Small Business Management 57 (2): 559-575. https://doi.org/10.1111/jsbm.12408

Regional Statistics, Vol. 10. No. 2. 2020: 117-141; DOI: 10.15196/RS100204 
Shumway, R. H.-Stoffer, D. S. (2017): Time Series Analysis and Its Applications, With R Examples, Fourth Edition. Springer, Switzerland.

TAsLIGIL, N. (2014): Turkiye'nin havaalanlari Turk Cografja Dergisi 0 (31): 259-281.

TEKELI, I. (2009): Modernizm, modernite ve Turkiye'nin kent planlama taribi (Vol. 8). TarihVakfi Yurt Yayinlari, Istanbul.

Togan, S. (2016): The Liberalization of Transportation Services in the EU and Turkey Oxford University Press, Oxford. https://doi.org/10.1093/acprof:oso/9780198753407.001.0001

TsiotAs, D. (2019): Detecting different topologies immanent in scale-free networks with the same degree distribution Proceedings of the National Academy of Sciences of the United States of America (PNAS) 116 (14): 6701-6706.

https://doi.org/10.1073/pnas.1816842116

TsiotAs, D.-Polyzos, S. (2015): Decomposing multilayer transportation networks using complex network analysis: a case study for the Greek aviation network Journal of Complex Networks 3 (4): 642-670.

TÜRKAN, S.-OZEL, G. (2019): Determinants of electricity consumption based on the NUTS 2 regions of Turkey: A panel data approach Regional Statistics 9 (1): 120-134. https://doi.org/10.15196/RS090105

WAlPOLE, R. E.-MYERS, R. H.-MYERS, S. L.-YE, K. (2012): Probability \& Statistics for Engineers \& Scientists 9th Ed., Prentice Hall, New York.

WANG, J.-BOnILlA, D.-BANISTER, D. (2016): Air deregulation in China and its impact on airline competition 1994-2012 Journal of Transport Geography 50: 12-23. https://doi.org/10.1016/j.jtrangeo.2015.03.007

YUN, B. I.-PETKOVIC, M. S. (2009): Iterative methods based on the signum function approach for solving nonlinear equations Numerical Algorithms 52 (4): 649-662. https://doi.org/10.1007/s11075-009-9305-0

\section{INTERNET REFERENCES}

Civil AviATiOn LAw (1983): Law no.2920, Available at: http://web.shgm.gov.tr/doc2/law2920.pdf (downloaded: January 18, 2020.)

DGCA (2014): Circular on Promoting New Flight Lines Directorate General of Civil Aviation. http://web.shgm.gov.tr/documents/sivilhavacilik/files/mevzuat/sektorel/genel geler/2014_ucus.pdf (downloaded: January 18, 2020.)

DGCA (2015): Circular on Promoting New Flight Lines Directorate General of Civil Aviation. http://web.shgm.gov.tr/documents/sivilhavacilik/files/mevzuat/sektorel/genel geler/Ucus_Hatlari_Tesvik_Genelgesi-2015.pdf (downloaded: January 18, 2020.)

Directorate General of Civil Aviation - DGCA (2017): Performance Report 2017 http://web.shgm.gov.tr/documents/sivilhavacilik/files/pdf/kurumsal/faaliyet/ 2017.pdf (downloaded: January 18, 2020.)

Regional Statistics, Vol. 10. No. 2. 2020: 117-141; DOI: 10.15196/RS100204 
GDAT (2017): Ulasan ve Erisen Turkiye: Havacilik ve Uzay Teknolojileri http://www.udhb.gov.tr/images/faaliyet/a5ec26a31a72281.pdf (downloaded: March January 3, 2018.)

ICAO (2017): Annual review of civil aviation International Civil Aviation Organization. https://www.icao.int/annual-report-2017/Documents/Annual.Report. 2017_Air\%20Transport\%20Statistics.pdf (downloaded: January 18, 2020.)

THE WORLD BANK (2018): GDP Growth of Turkey (Annual \%). https://data.worldbank.org/indicator/NY.GDP.MKTP.KD.ZG?locations=TR (downloaded: January 18, 2020.)

THY (2018): History of Turkish Airlines https://investor.turkishairlines.com/tr/thy-anonimortakligi/tarihce. (downloaded: January 18, 2020.)

TURKSTAT (2010): Istatistik Gostergeler 1923-2009. Turkiye Istatistik Kurumu Yayini Ankara.

http://www.tuik.gov.tr/Kitap.do?metod=KitapDetay\&KT_ID=0\&KITAP_ID $=160$. (downloaded: January 18, 2020.)

WikIPEDIA (2020): Aviation in Turkey https://en.wikipedia.org/w/index.php?title=Aviation_in_Turkey\&oldid=91913 7939 (downloaded: January 19, 2020.) 